KOŚCIÓŁ I PRAWO 8(21) 2019, nr 2, s. 49-71

DOI: http://dx.doi.org/10.18290/kip.2019.8.2-3

\author{
Bartosz Trojanowski
}

\title{
ZMIANY I ADNOTACJE W KSIĘGACH METRYKALNYCH Z UWZGLECDNIENIEM KWESTII PROBLEMATYCZNYCH W TEJ MATERII W OBOWIĄZUJĄCYCH PRZEPISACH O OCHRONIE DANYCH OSOBOWYCH W POLSCE
}

Po raz pierwszy o księgach metrykalnych w powszechnym ustawodawstwie wzmiankę możemy znaleźć w postanowieniach Soboru Trydenckiego dotyczących reformy małżeństwa, gdzie Ojcowie soborowi wyraźnie wskazują, że „proboszcz będzie posiadał księgę”, w niej ma on dokonać stosownych adnotacji po zawartym małżeństwie. Jednak to nie pierwszy ślad takiego nakazu prowadzenia ksiąg parafialnych, ponieważ w prawie partykularnym szybciej pojawiały się wezwania do prowadzenia tego rodzaju ksiąg². Również na ziemiach polskich Kościół posiadał praktykę przechowywania najważniejszych dokumentów [Kufel 2005, 35-49]. Historia tego zagadnienia jest bardzo bogata i posiada już swoje naukowe opracowanie [Gręźlikowski 2014, 126-46]. W artykule zbadane zostanie zagadnienie

Ks. DR BARTOSZ TROJANOwSKI - Kuria Metropolitalna Wrocławska; adres do korespondencji: Plac Katedralny 14, 50-329 Wrocław, Polska; e-mail: b.trojanowski@hadak.pl; https://orcid.org/0000-0003-0158-1647

${ }^{1}$ Sobór Trydencki, Kanony o reformie małżeństwa, rozdział I, m, w: Dokumenty Soborów Powszechnych. Tekst łaciński, polski. T. IV/1 (1511-1870). Lateran V, Trydent, Watykan I, układ i oprac. A. Baron, H. Pietras, Wydawnictwo WAM. Księża Jezuici, Kraków 2007, s. 723.

${ }^{2}$ Synody: w Tournai (Belgia) 1481 - prowadzenie księgi chrztów, w Alcala (Hiszpania) 1497 - zobowiązanie do prowadzenia księgi chrztów i ślubów, w Augsburgu 1548 odbył się w Dillingen - prowadzenie księgi chrztów, ślubów i zgonów oraz spis Komunii Wielkanocnej, a także w Chartres 1526, Toulouse 1531, De Sens 1534, d’Angers 1544, Narbonne 1555, Rodez 1552, Paris 1557, Reims 1558 [Kurpas 1961, 19]. 
możliwości i obowiązku dokonywania zmian metrykalnych oraz dokonywania adnotacji w księgach metrykalnych w obowiązującym ustawodawstwie kanonicznym, ponieważ wśród wielu terminów dotyczących ochrony danych osobowych pojawiają się takie określenia, jak „sprostowanie lub usunięcie danych osobowych, które są nieprawidłowe”. Zarówno prawo europejskie $^{3}$, jak i kanoniczne prawo partykularne w Polsce ${ }^{4}$ dotyczące ochrony danych rozpoznają prawo do żądania sprostowania danych lub prawo do żądania usunięcia danych. Dlatego w myśl nowych wyzwań warto przeanalizować obowiązujące przepisy prowadzenia ksiąg metrykalnych wraz $\mathrm{z}$ uwzględnieniem prawa związanego $\mathrm{z}$ ochroną danych osobowych.

\section{PRZEPISY PRAWA KANONICZNEGO O ZAPISACH W KSIĘGACH METRYKALNYCH}

\subsection{Ustawodawstwo powszechne dotyczące prowadzenia ksiąg metrykalnych}

Prowadzenie ksiąg metrykalnych ma niezwykle istotny aspekt w zbawczym posługiwaniu Kościoła wobec ludzi, jest to bowiem udokumentowanie najważniejszych wydarzeń w życiu sakramentalnym poszczególnych osób przynależących do Kościoła, a także tych, które do niego przynależały. Stąd też prowadzenie ksiąg metrykalnych (ochrzczonych, bierzmowanych, zawartych małżeństw, zmarłych) jest unormowane przez prawo powszechne. Wyraźnie najważniejsze miejsce wśród ksiąg metrykalnych zajmuje księga ochrzczonych. Jest to spowodowane tym faktem, że już samo przyjęcie chrztu św. jest wydarzeniem, które zmienia osobę pod względem ontologicznym zarówno w porządku łaski, jak również w porządku prawa [Wenz 2008, 121].

\footnotetext{
${ }^{3}$ Por. rozporządzenie Parlamentu Europejskiego i Rady (UE) 2016/679 z dnia 27 kwietnia 2016 r. $W$ sprawie ochrony osób fizycznych $w$ związku $z$ przetwarzaniem danych osobowych $i \mathrm{w}$ sprawie swobodnego przepływu takich danych oraz uchylenia dyrektywy 95/46/WE (ogólne rozporządzenie o ochronie danych), Dz. Urz. UE L 119/1 [dalej cyt.: RODO].

${ }^{4}$ Por. Dekret ogólny $w$ sprawie ochrony osób fizycznych ${ }^{w}$ związku z przetwarzaniem danych osobowych $w$ Kościele katolickim (13.03.2018), „Akta Konferencji Episkopatu Polski” 30 (2018), s. 31-45 [dalej cyt.: Dekret ODO].
} 
W związku z tym ustawodawca powszechny w Kodeksie Prawa Kanonicznego z 1983 r. ${ }^{5}$ podkreślając istotę rzetelnego prowadzenia księgi metrykalnej zawierającej adnotację o chrzcie, nakłada na proboszcza miejsca udzielenia chrztu obowiązek bezzwłocznego i dokładnego zapisania danych osoby ochrzczonej, rodziców chrzestnych lub świadków oraz szafarza, datę i miejsce urodzenia i chrztu (kan. $877 \S 1$ ).

Drugim znaczącym przepisem prawa dotyczącym prowadzenia ksiąg metrykalnych jest kanon określający obowiązki i prawa proboszcza. Wśród jego obowiązków wspomniana jest konieczność prowadzenia ksiąg parafialnych, a mianowicie księgi ochrzczonych, małżeństw, zmarłych oraz innych, które są wymagane prawem partykularnym ustanowionym przez konferencję biskupów lub biskupa diecezjalnego (kan. $535 \S 1$ ).

Warto zauważyć, że ustawodawca powszechny nakłada przede wszystkim na proboszcza obowiązek troski o to, by księgi metrykalne były prowadzone rzetelnie. Z kan. $535 \S 2$ wynika istota i komplementarność księgi ochrzczonych. W związku z tym faktem $\mathrm{w}$ artykule zostanie przede wszystkim rozważony temat adnotacji i zmian metrykalnych, a większość uwagi zostanie poświęcona księdze ochrzczonych, ponieważ w niej zawarte są również zapisy dotyczące istotnych etapów w życiu osób wierzących, a także tych, które dokonały aktu apostazji czy schizmy.

\subsection{Obowiązek wynikający z urzędu do czuwania nad księgami metrykalnymi}

Obowiązek czuwania nad tym, by księgi metrykalne w parafii były właściwie spisywane i przechowywane spoczywa na proboszczu (kan. $535 \S 1$ ). Główny ciężar odpowiedzialności za rzetelność ich prowadzenia i dbałość o ich przechowywanie spoczywa na tym, który odpowiada za parafię. Jednak mimo, iż ustawodawca kościelny stanowi, że to proboszcz otrzymuje informacje o wydarzeniach, które wpływają na status kanoniczny wiernych (kan. 895, 1054, 1122), to jednak można stwierdzić, że nie jest on zobowiązany do tego, aby zawsze osobiście dokonywać zapisu, ponieważ w jego

${ }^{5}$ Codex Iuris Canonici auctoritate Ioannis Pauli PP. II promulgatus (25.01.1983), AAS 75 (1983), pars II, s. 1-317; tekst polski w: Kodeks Prawa Kanonicznego, przekład polski zatwierdzony przez Konferencję Episkopatu, Pallottinum, Poznań 1984 [dalej cyt.: KPK/83]. 
pracy duszpasterskiej wspierają go także wikariusze ${ }^{6}$. Świeccy mogą wprawdzie wykonywać w pracy kancelaryjnej pewne zadania, jednak należy podkreślić, iż powinny to być czynności, takie jak pomoc przy pracach biurowych czy sporządzaniu kopii ksiąg metrykalnych [Wenz 2013, 229].

Biskup diecezjalny jest również zobowiązany do troski o wszystkich wiernych powierzonych swojej pieczy (kan. 383), ponieważ w powierzonym mu Kościele partykularnym sprawuje władzę ustawodawczą, wykonawczą i sądowniczą (kan. 391 § 1). W kontekście dbałości o prowadzone księgi metrykalne zadania biskupa diecezjalnego w sposób szczególny realizowane są podczas wizytowania diecezji, kiedy to może upewnić się o właściwym przechowywaniu akt i dokumentów, a w ten sposób zrealizować swój obowiązek wynikający z przepisów prawa (por. kan. 396, 491). W dyrektorium o pasterskiej posłudze biskupów Apostolorum Successores podkreślone zostało, że jednym z elementów wizytacji biskupa jest weryfikacja prowadzenia ksiąg parafialnych ${ }^{7}$. Podczas wizytacji w parafii biskup powinien prowadzone przez parafię księgi metrykalne przejrzeć, przekonać się o poprawności zastosowanych form zapisów oraz prawidłowości prowadzenia tych ksiąg. W kontroli tych dokumentów biskup może posłużyć się pomocą wyznaczonych kapłanów (por. kan. 396 §), którzy ze względu na pracę w kurii diecezjalnej zajmują się na co dzień troską o merytoryczną poprawność kwestii administracji kościelnej w oparciu o przepisy prawa kanonicznego [Wenz 2013, 221]. W Apostolorum Successores Kongregacja ds. Biskupów postuluje, aby to dziekani zajmowali się weryfikacją prowadzenia ksiąg, ponieważ w ten sposób biskup będzie mógł poświęcić czas na spotkania osobiste, zgodnie z jego pasterskim urzędem. Podobne rozwiązanie zawierała instrukcja Ecclesiae imago: ,jeśli chodzi o sprawdzenie ksiąg parafialnych czy też prowadzonych przez inne instytucje, o wizytację miejsc świętych i przejrzenie naczyń oraz szat liturgicznych lub o sprawdzenie administracji majątkiem kościelnym, to biskup wyznacza do tego odpowiednich prezbiterów, zwłaszcza dziekanów"'. Jest to zgodne z przepisem

${ }^{6}$ Przepisy o prowadzeniu ksiąg parafialnych: ochrzczonych, bierzmowanych, małżeństw i zmarłych oraz ksiąg stanu dusz, „Wiadomości Kościelne” 2/5-7 (1947), s. 92-99.

${ }^{7}$ Congregazione per i Vescovi, Direttorio per il ministero pastorale dei vescovi Apostolorum Successores (22.02.2004), Libreria Editrice Vaticana, Città del Vaticano 2004; tekst polski w: Ustrój hierarchiczny Kościoła. Wybór źródel, red. i oprac. W. Kacprzyk, M. Sitarz, Wydawnictwo KUL, Lublin 2006, s. 517-711, nr 222.

${ }^{8}$ Congregatio pro Episcopis, Directorium Ecclesiae imago de pastorali ministerio Episcoporum (22.02.1973), Typis Polyglottis Vaticanis 1973; tekst polski w: Ustrój hierarchiczny Kościoła. Wybór źródeł, s. 403-516, nr 168. 
prawnym zawartym w KPK/83, gdzie obowiązek związany z księgami parafialnymi nakłada ustawodawca powszechny na dziekanów podczas ich wizytacji, mają oni „czuwać (...) żeby księgi parafialne były właściwie spisywane i należycie przechowywane" (kan. $555 \S 1,3^{\circ}$ ). Dziekan powinien również zatroszczyć się, aby podczas choroby lub śmierci, oprócz zapewnienia pomocy duchownemu, stać na straży, aby nie zostały zabrane księgi i dokumenty, lub nie zaginęły (kan. 555 § 3). Przedmiot wizytacji dziekańskiej jest zatem określony w KPK/83 pośrednio poprzez nakreślenie obowiązku dziekana, natomiast jej częstotliwość oraz bardziej szczegółowe postanowienia stanowić powinno prawo partykularne [Adamczyk 2017, 101]. Wizytacja dziekańska ma ożywić nie tylko gorliwość apostolską, ale również ukierunkować na najbliższą przyszłość sprawy administracyjnogospodarcze, a zatem także zmobilizować proboszcza do rzetelnego prowadzenia ksiąg metrykalnych, gdyby w tej kwestii miał jakieś zaległości [Sztafrowski 1992, 48]. Współdzielenie odpowiedzialności za prowadzenie ksiąg metrykalnych oraz wprowadzenie obowiązku weryfikowania ich aktualności i właściwego wypełniania, a także troska o zabezpieczenie tych zapisów jako istotnych danych osobowych, mówiących o życiu wiernych, dla wspólnoty Kościoła pozwalają wyprowadzić konkluzję, że wszystkie te aspekty podkreślają powagę zagadnienia prowadzenia ksiąg metrykalnych i ich znaczenie dla wspólnoty Kościoła.

\subsection{Ustawodawstwo partykularne dotyczące prowadzenia ksiąg metrykalnych}

Dokument, który w sposób szczególny będzie przedmiotem analizy w kwestii ksiąg metrykalnych jest zatytułowany Przepisy o prowadzeniu ksiąg parafialnych: ochrzczonych, bierzmowanych, małżeństw i zmarłych oraz księgi stanu dusz. Dokument ten został określony jako przygotowany przez Konferencję Episkopatu Polski na mocy autorytetu moralnego, moc prawną natomiast uzyskał na skutek promulgowania go przez poszczególnych biskupów diecezjalnych [Janczewski 1997, 134]. Z tego względu w niektórych szczegółowych rozwiązaniach ten dokument w poszczególnych diecezjach może się różnić (np. w podanych terminach sporządzania kopii ksiąg metrykalnych do archiwum diecezjalnego), choć co do swej istoty jest jednolity. I choć był promulgowany przed 1983 r., to jednak w myśl kan. 20 zachowuje swoją moc prawną. 
W dokumencie tym znajduje się mobilizacja do dalszego starannego spisywania ksiąg metrykalnych. Trzeba tutaj podkreślić trudną sytuację duszpasterską związaną z brakiem takich ksiąg ze względu na zniszczenia i relokacje związane $\mathrm{z}$ działaniami wojennymi [tamże]. Obowiązek taki spoczywa przede wszystkim na proboszczu lub jego zastępcy, wspomniana jest osobista odpowiedzialność za ten fakt (kan. 2383 Kodeksu Prawa Kanonicznego z 1917 r. ${ }^{9}$ ). Wikariusz parafialny pomaga w wypełnianiu tego obowiązku. Przepisy o prowadzeniu ksiąg parafialnych doprecyzowują, że księgę ochrzczonych spisuje się w 2 jednobrzmiących egzemplarzach tak, aby jeden $\mathrm{z}$ nich pozostał na miejscu do użytku parafialnego i zainteresowanych, natomiast drugi powinien być przesłany do kurii diecezjalnej lub archiwum diecezjalnego (pkt I, nr 2-3). Przepis ten ma na celu zapobiec nieodwracalnej utracie danych zawartych w księgach metrykalnych. Chociaż przepisy powstały zaraz po II wojnie światowej, to także dzisiaj mają ogromne znaczenie $\mathrm{w}$ kwestii zabezpieczenia przed zniszczeniem ksiąg metrykalnych, a w konsekwencji utratą danych w nich zawartych.

Należy również pamiętać, że na szczeblu diecezjalnym mogą pojawić się inne ustawy lub instrukcje oraz postanowienia synodów dotyczące kwestii prowadzenia ksiąg metrykalnych.

\section{ZMIANY W KSIĘGACH METRYKALNYCH}

\subsection{Adnotacje $\mathrm{w}$ księgach metrykalnych a zmiany metrykalne}

Ustawodawca powszechny określił, jakie adnotacje mają znaleźć się w księdze ochrzczonych (kan. 535 § 2). Należy zatem podkreślić, że odnotowanie $\mathrm{w}$ księdze chrztów nie jest zmianą metrykalną w znaczeniu nanoszenia poprawek. Adnotacje dotyczą zmiany statusu kanonicznego danej osoby lub zawierają dodatkowe informacje dotyczące osoby, o której mówi zapis w księdze. KPK/83 zawiera przepisy nakazujące zapisanie w odpowiedniej rubryce $\mathrm{z}$ adnotacjami przyjęcie sakramentu bierzmowania (kan. 895), zawarcie małżeństwa sakramentalnego i kanonicznego z wyjątkiem małżeństwa tajnego (kan. 1133), również te małżeństwa, które zostały

\footnotetext{
${ }^{9}$ Codex Iuris Canonici Pii X Pontificis Maximi iussu digestus Benedicti Papae XV auctoritate promulgatus (27.05.1917), AAS 9 (1917), pars II, s. 1-593 [dalej cyt.: KPK/17].
} 
uważnione powinny zostać zapisane (kan. 1123). Małżeństwa dotyczy również wyrok stwierdzający nieważność zawartego związku, a zatem także ten fakt powinien być zapisany i jeśli zostały nałożone klauzule wzbraniające zawieranie w przyszłości małżeństwa bez zgody ordynariusza miejsca, również one powinny się tam znaleźć (kan. 1682 §), małżeństwo rozwiązane zgodnie z prawem przez dyspensę papieską od małżeństwa niedopełnionego (kan. 1123) lub na podstawie deklaracji biskupa diecezjalnego o domniemanej śmierci współmałżonka i choć taki obowiązek nie został nałożony, to przez analogię do innych temu podobnych należałoby dokonać odnotowania takiego faktu (kan. 1707). W księdze ochrzczonych należy zapisać również fakt, że dany mężczyzna przyjął święcenia w poszczególnych stopniach diakonatu, prezbiteratu i episkopatu (kan. 1054). W przypadku uzyskania dyspensy od celibatu i obowiązków wynikających z przyjętych święceń taki fakt również należy zapisać w księdze metrykalnej (kan. 290, $3^{\circ}$ ). Również w sytuacji stwierdzenia nieważności święceń powinien znaleźć się odpowiedni zapis (kan. 1712; 290, $1^{\circ}$ ), a także karne przeniesienie do stanu świeckiego (kan. 290, $2^{\circ}$ ). W księdze chrztów należy zapisać złożenie ślubów wieczystych w instytucie zakonnym (kan. $535 \S 2$ ), jak również uzyskanie zwolnienia ze ślubów zakonnych. Fakt dokonania zgodnie $\mathrm{z}$ prawem przysposobienia powinien zostać odnotowany zgodnie $\mathrm{z}$ przepisami prawa kanonicznego $\mathrm{z}$ uwzględnieniem prawa partykularnego (kan. $535 \S 2)^{10}$. W przypadku zmiany Kościoła sui iuris należy odnotować fakt przejścia z jednego Kościoła sui iuris do drugiego (kan. $535 \S 2)^{11}$.

Ustawodawca powszechny daje możliwość dookreślenia innych adnotacji w przepisach ustanawianych przez konferencję biskupów lub biskupa diecezjalnego, podkreślając ich kompetencje do stanowienia prawa partykularnego $\mathrm{w}$ zakresie prowadzenia ksiąg metrykalnych w parafiach (kan. $535 \S 1$ ).

Wszystkie adnotacje dokonane w księdze ochrzczonych „muszą być zawsze uwidocznione w metryce chrztu" (kan. $535 \S 2$ ). Wyjątek stanowią adnotacje, które zostały utajnione zgodnie z prawem, np. kwestia przyspo-

${ }^{10}$ Dekret ogólny Konferencji Episkopatu Polski dotyczący sporządzenia i modyfikacji aktu chrztu W związku z przysposobieniem, „Akta Konferencji Episkopatu Polski” 30 (2018), s. 46-47 [dalej cyt.: Dekret o przysposobieniu].

${ }^{11}$ Rada Prawna Konferencji Episkopatu Polski, Pro memoria dotyczące relacji duszpasterskich Kościoła lacińskiego z katolikami Kościołów wschodnich (4.10.2018), https://archidiecezjalubelska.pl/dokumenty-kep/ [dostęp: 12.04.2019]. 
sobienia, jeśli taka jest wola rodziców przysposabiających (Dekret o przysposobieniu, nr 9). Podstawę prawną do takiego postępowania daje dekret Konferencji Episkopatu Polski o ochronie danych osobowych z 2018 r. (art. 11 ust. 4). Należy zauważyć, że przepisy te są przeciwne brzmieniu normy kodeksowej, dlatego w ich interpretacji należy zastosować kan. 29 i 20. A zatem trzeba uznać, że utajnione dane nie mogą być zapisane za każdym razem, kiedy jest wydawane świadectwo chrztu, a jedynie jeśli potrzebne jest to do stwierdzenia braku przeszkód do małżeństwa i to w drodze, która nie narusza danej tajemnicy (Dekret o przysposobieniu, nr 9).

Wyraźnie zatem jest rozróżnione w prawie dokonywanie adnotacji w metrykach chrzcielnych, do których zobowiązuje prawo powszechne lub prawo partykularne, od zmian metrykalnych. Na zmiany zgodę powinien wyrazić ordynariusz miejsca. Choć również adnotacje często dokonują się ze względu na informację właśnie od ordynariusza miejsca (por. kan. 1682 $\S 2$ ), to jednak można stwierdzić, że zgoda na ich dokonanie jest $\mathrm{z}$ mocy prawa, a nie na zasadzie decyzji władzy administracyjnej.

\subsection{Możliwość dokonywania zmian}

Chociaż ustawodawca powszechny nakłada na proboszczów obowiązek rzetelnego i natychmiastowego zapisu w księgach metrykalnych faktu o przyjętych sakramentach oraz innych aktach, które wpływają na sytuację kanoniczną osoby ochrzczonej, to jednak dopuszcza się możliwość popełnienia błędu lub sytuacji, w których w przyszłości dochodzi do jakiejś istotnej zmiany w dokumentach cywilnych i w konsekwencji następuje rozbieżność między dokumentami kościelnymi a cywilnymi. Dlatego w przepisach partykularnych przedstawiono normę o możliwości dokonania zmiany w księgach metrykalnych, na podstawie jakiegoś dokumentu oraz za zgodą kurii diecezjalnej. Sam fakt takiej zgody może być już traktowany jako dokonanie samej korekty i dlatego należy przyjąć, że proboszcz po dokonaniu zmiany nie musi informować archiwum diecezjalnego, jeśli nie jest to wyraźnie wyartykułowane [Wenz 2008, 108]. Istotne jest nieustanne uświadamianie proboszczom, wikariuszom i innym kapłanom wspomagającym pracę duszpasterską, a także diakonom oraz personelowi pracującemu w kancelarii parafialnej, że nie wolno dokonywać żadnych zmian w księgach metrykalnych na własną rękę, czyli bez zgody kurii diecezjalnej. Wyjątkiem mogą być oczywiste błędy w zapisie, które nie 
zmieniają istotnie możliwości identyfikacji osoby (np. zmiana imienia z Wiesław na Wiesława - nie może być potraktowane jako błąd pisarski). Należy uwzględnić, że prawo partykularne może wymagać zgody ordynariusza nawet przy oczywistych błędach pisarskich, ponieważ w ten sposób zapewnia korektę w kopiach przekazanych do kurii lub archiwum. Ma to również swoje znaczenie w obliczu ostatnich zmian przepisów dotyczących ochrony danych osobowych.

\subsection{Zmiany metrykalne wobec obowiązujących przepisów o ochronie danych osobowych}

W dekrecie Konferencji Episkopatu Polski dotyczącym ochrony danych osobowych znajduje się artykuł, który przedstawia prawo do sprostowania danych (Dekret ODO, art. 12). Jest to dokument, który wprowadza ogólnopolskie przepisy dotyczące zmian metrykalnych (oraz innych danych) $\mathrm{w}$ ramach prawa do sprostowania danych. W art. 12 ust. 4 KEP stwierdza, że sprostowanie danych mówiących o stanie kanonicznym osoby może być dokonane tylko za zgodą ordynariusza miejsca lub wyższego przełożonego instytutu życia konsekrowanego lub stowarzyszenia życia apostolskiego. Trzeba tutaj dodać, że w przypadku zmian metrykalnych w księgach chrzcielnych będzie to jednak zgoda ordynariusza miejsca, na terytorium, którego znajduje się parafia, lub innej kompetentnej władzy, jeśli zmiana byłaby jej zastrzeżona przez prawo powszechne lub sprawa trafiłaby do niej w wyniku rekursu. W przypadku niekompletnych danych osobowych osoba, której dotyczą dane może żądać uzupełnienia tych danych lub dokonania adnotacji w zbiorze danych. Prawo takie przysługuje jednak tylko w uzasadnionym zakresie (Dekret ODO, art. 13 ust. 1), np. uzupełnienie adnotacji o bierzmowaniu w księdze ochrzczonych. Wniosek taki powinien jednak być udokumentowany (Dekret ODO, art. 12 ust. 2). W takim przypadku nie jest wymagana zgoda ordynariusza miejsca.

Dekret dotyczący ochrony danych osobowych dopuszcza również prawo do żądania usunięcia danych. Jednak należy tutaj zachować bardzo wielką ostrożność, ponieważ takie prawo nie przysługuje w przypadku, gdy dane dotyczą udzielonych sakramentów bądź w inny sposób odnoszą się do kanonicznego statusu osoby (Dekret ODO, art. 14 ust. 4). W takim wypadku administrator jest zobowiązany do niewykorzystywania danych objętych 
wnioskiem bez zgody ordynariusza miejsca lub odpowiednio innego wyższego przełożonego.

\section{KWESTIE PROBLEMATYCZNE PRZY WPROWADZANIU ZMIAN METRYKALNYCH}

W kwestiach zmian metrykalnych należy pamiętać, że dekret ogólny KEP nie wprowadził zmian dotyczących innych kwestii zapisów metrykalnych, biorąc także pod uwagę ochronę danych osobowych. Należy zatem stosować przepisy dotychczas obowiązujące ze szczególnym uwzględnieniem praw wynikających z prawa każdego wiernego do ochrony danych osobowych.

\subsection{Apostazja}

Jeśli chodzi o kwestię wystąpień z Kościoła mają zastosowanie przepisy prawne zawarte w Dekrecie ogólnym Konferencji Episkopatu Polski w sprawie wystąpień $z$ Kościoła oraz powrotu do wspólnoty Kościoła z dnia 7 października 2015 r., a który obowiązuje od 19 lutego 2016 r. $^{12}$ Dlatego w przypadku woli wystąpienia z Kościoła katolickiego, czyli dokonania aktu apostazji, nie należy ulegać naciskom ze strony osób zainteresowanych o natychmiastowe wykreślenie $\mathrm{z}$ ksiąg metrykalnych ich danych osobowych. W Dekrecie ogólnym w art. $7 \mathrm{KEP}$ stwierdza, że po weryfikacji oświadczenia woli o wystąpieniu, to ordynariusz miejsca poleca proboszczowi parafii miejsca chrztu dokonanie stosownego wpisu do ksiąg ochrzczonych, nawet jeśli parafia chrztu jest tożsama z parafią złożenia wniosku. Duszpasterze powinni pamiętać, że w przypadku apostazji, jak również innych kwestii związanych z zapisami metrykalnymi rozporządzenie europejskie daje autonomię kościołom i związkom wyznaniowym, które posiadają własny system prawny dotyczący ochrony danych osobowych (RODO, art. 91.1), Kościół katolicki posiada taki system, którego filarem jest dekret ogólny KEP. Jest to istotny aspekt, gdyż osoby, które pragną wystąpić z Kościoła katolickiego często posługują się różnego

${ }^{12}$ Dekret ogólny Konferencji Episkopatu Polski w sprawie wystąpień z Kościoła oraz powrotu do wspólnoty Kościoła (7.10.2015), „Akta Konferencji Episkopatu Polski” 27 (2015), s. 101-104. 
rodzaju formularzami, w których są odwołania do aktów normatywnych cywilnych, często już nieobowiązujących, jak np. do ustawy o ochronie danych osobowych z 1997 r. Można zatem spodziewać się, że mogą pojawić się również odwołania do RODO, a co więcej przywołujące np. art. 83 RODO, który przewiduje nałożenie wysokich kar pieniężnych.

Dekret z 7 października 2015 r. nie przewiduje wystawiania żadnego zaświadczenia potwierdzającego fakt wystąpienia z Kościoła. Odstępcy może jednak być wystawione świadectwo chrztu $\mathrm{z}$ adnotacją o wystąpieniu (art. 11). To jedyna forma potwierdzenia, że apostazja osiągnęła swój skutek prawny.

\subsection{Transseksualizm i obojnactwo}

Inną kwestią problematyczną jest przetwarzanie danych osób transseksualnych, które wnoszą o zmianę ich danych osobowych. Również w tym przypadku nie należy sugerować się obowiązkiem zmiany danych wynikającym z RODO, ale właśnie powoływać się na Dekret ODO, w szczególności o niemożliwości dokonywania zmian w danych osób, które otrzymały sakramenty w Kościele katolickim, bez zgody ordynariusza (art. 12 ust. 4) oraz o usunięciu danych w kwestiach dotyczących sakramentów (art. 14 ust. 4). Należy tutaj przywołać uzasadnienie ówczesnego Prefekta Kongregacji Nauki Wiary, który stwierdził, że trzeba założyć, że zmieniony status wiernego związany ze skutkami cywilnymi - otrzymanie nowej tożsamości w dokumentach anagraficznych - nie może jednak determinować zmiany tożsamości kanonicznej danej osoby - płci męskiej lub żeńskiej - określonej w momencie narodzin, a zapisanej w księdze chrztów, gdzie jest określona płeć ochrzczonej osoby poprzez zapisanie właściwego imienia (imion). Z tego powodu nie może być wprowadzona jakakolwiek zmiana będąca konsekwencją operacyjnej zmiany płci ${ }^{13}$. W takich przypadkach wydaje się słuszne dokonanie adnotacji w uwagach wprowadzając nowe dane tak, aby był widoczny stan kanoniczny, w szczególności płeć przed operacją (na podstawie imienia i nazwiska). Nuncjatura Apostolska w Polsce w swoim liście zawarła najważniejsze postanowienia z listu Kongregacji Nauki Wiary przypominającego o tym delikatnym zagadnieniu w 2004 r. i pouczyła,

${ }^{13}$ List Prefekta Kongregacji Nauki Wiary z 28 września 2002 r. [brak numeru protokołu], w: Archiwum KEP. 
że w przypadku osób, które poddały się zabiegowi zmiany płci i uzyskały wyrok sądowy dotyczący zmiany imienia i płci w aktach stanu cywilnego, należy na marginesie księgi ochrzczonych wprowadzić odpowiednią adnotację, w której powinna być zawarta decyzja sądowa wraz z sygnaturą wyroku lub datą wydania zmienionego dokumentu państwowego potwierdzającego zmienioną tożsamość. Jeśli nie ma przeszkód należałoby zachować kopię takiego dokumentu, mając jednak na uwadze, iż taki dokument ma charakter poufny i w żadnym przypadku nie może być udostępniany osobom trzecim. Co więcej, w odpisach aktów chrztu czy bierzmowania nie można zamieszczać adnotacji o cywilnej zmianie płci ${ }^{14}$. Dane te w sposób poufny należałoby przekazać odpowiednim władzom kościelnym w przypadku ewentualnego podjęcia próby zawarcia małżeństwa, przyjęcia święceń lub chęci wstąpienia do instytutu życia konsekrowanego lub stowarzyszenia życia apostolskiego. Te sytuacje, które mogą mieć miejsce w przyszłości danej osoby, domagają się takich zapisów na marginesie księgi chrztów oraz ewentualnego przechowywania kopii dokumentów dla potwierdzenia takiego zapisu ${ }^{15}$.

Jeszcze bardziej skomplikowana sytuacja może mieć miejsce w przypadku hermafrodytyzmu zarówno prawdziwego, jak i rzekomego. Należy bowiem rozróżnić kwestie transseksualizmu, który przynależy do kategorii patologii o typowo psychicznym charakterze od różnych form obojnactwa, które cechuje się wadami w ukształtowaniu narządów płciowych, a przez to określeniu płci cielesnej. Jednakże nie można wykluczać, że obojnactwu fizycznemu może towarzyszyć również poważne zaburzenie sfery psychicznej, nie wykluczając transseksualizmu ${ }^{16}$. W każdym $\mathrm{z}$ tych przypadków może nastąpić błąd w zapisie w księgach metrykalnych, a nawet niewłaściwe nadanie imienia przy chrzcie. Dlatego w takich szczególnie skomplikowanych sytuacjach już przed chrztem należałoby skonsultować się z ordynariuszem miejsca, to pozwoliłoby określić zawiłą sytuację, jeśli sprawa byłaby skomplikowana należałoby zwrócić się do Kongregacji Nauki Wiary. Gdyby problem wystąpił po chrzcie św., w każdym przypadku należy

${ }^{14}$ List Nuncjusza Polski Abpa Józefa Kowalczyka z 4 października 2004 r., N.11. 170/04, w: Archiwum KEP.

${ }^{15}$ List Prefekta Kongregacji Nauki Wiary z 28 września 2002 r.

${ }^{16}$ List Kongregacji Nauki Wiary, Nota dotycząca skutków kanonicznych transseksualizmu w odniesieniu do życia konsekrowanego z 28 września 2002 r. oraz Nota dotycząca skutków kanonicznych transseksualizmu w odniesieniu do małżeństwa i kapłaństwa z 28 września 2002 r., w: Archiwum KEP. 
zwrócić się do odpowiedniej dykasterii Stolicy Świętej kompetentnej w tej sprawie. Zakłada się tutaj bowiem dwie kwestie: po pierwsze odwołanie się w sytuacjach trudnych do Stolicy Apostolskiej powinno być raczej normą, a nie wyjątkiem, po drugie należy uznać konieczność zapobiegania zgorszeniu wynikającemu z ewentualnych niejednolitych kryteriów osądu zastosowanych w przypadku pozostania na szczeblu Kościołów partykularnych w tak delikatnej kwestii. W 2002 r. papież Jan Paweł II, mając na uwadze trudności płynące $\mathrm{z}$ zetknięcia się $\mathrm{z}$ tak delikatnymi kwestiami, kompetencje w tej sprawie postanowił powierzyć Kongregacji Nauki Wiary, aż do odwołania poprzez inne rozporządzenie ${ }^{17}$. Jest to jedyny przypadek, kiedy zgody na zmianę metrykalną nie może wydać ordynariusz miejsca, ale jest ona zastrzeżona kompetentnej dykasterii Stolicy Świętej. Świadomość jednak niewielkiej liczby takich przypadków w porównaniu do poprzedniego zagadnienia potwierdza, że niebezpieczeństwo dokonywania nieuprawnionych zmian metrykalnych w tej materii jest dużo mniejsze.

\subsection{Przysposobienie dziecka}

Ostatnią kwestią jest adopcja dziecka już ochrzczonego. Zawsze za zgodą kurii biskupiej można dokonywać zmian metrykalnych. Nie podlega to wątpliwości, ponieważ już od 1947 r. był obowiązek uzyskania zgody na zmiany w metrykach. Jednak sam zapis rodziców, którzy przysposobili dziecko było już kwestią zależącą od praktyki danej kurii diecezjalnej. Dlatego Konferencja Episkopatu Polski w 2017 r. wydała stosowny dokument ujednolicający praktykę w całym kraju (Dekret o przysposobieniu). Ze względu na temat tego artykułu w pierwszej kolejności zostanie przeanalizowana kwestia przysposobienia po przyjętym chrzcie, warto jednak podkreślić, że dekret ogólny biskupów polskich zgromadzonych na 375 . Zebraniu Plenarnym Konferencji Episkopatu Polski określa również zasady zapisów w księgach metrykalnych dziecka przysposobionego przed chrztem. Ten drugi aspekt również zostanie omówiony, ponieważ prawidłowy zapis w księgach metrykalnych pomoże uchronić przed koniecznością wprowadzania zmian metrykalnych w przyszłości.

W przypadku dziecka już ochrzczonego rodzice, którzy przysposobili dziecko, ewentualnie sam zainteresowany, jeśli osiągnął już pełnoletniość,

\footnotetext{
17 Tamże.
} 
kierują do ordynariusza miejsca prośbę za pośrednictwem proboszcza parafii, w której został sporządzony lub ma zostać sporządzony akt chrztu. To ordynariusz miejsca podejmuje decyzję o dokonaniu wpisu i o jego formie (Dekret o przysposobieniu, art. 1). Nie można zatem dokonywać wpisu bez zgody ordynariusza miejsca, ani zmieniać formy zapisu, która została przez niego podana. Do takiego wniosku należy dołączyć stosowne dokumenty: sądowe orzeczenie przysposobienia, odpis zupełny aktu urodzenia i akt chrztu dziecka przysposobionego (Dekret o przysposobieniu, art. 2-3). Jeśli jest trudne uzyskanie tego dokumentu, kuria diecezjalna powinna nakazać przeprowadzenie stosownej kwerendy, jeśli taka jeszcze nie została dokonana przez samego proboszcza. Kwerenda powinna odbyć się przynajmniej w miejscach najbardziej prawdopodobnych co do możliwego miejsca udzielenia chrztu dziecku. Chodzi tutaj o miejsce zamieszkania rodziców dziecka lub miejsce urodzenia dziecka w oparciu o dostępne dane osoby przysposobionej, jej rodziców biologicznych i informacji na temat miejsca ich zamieszkania. Kwerenda przed chrztem jest konieczna, ponieważ ze względu na charakter sakramentalny, który zostawia chrzest św., jednym z warunków do jego przyjęcia jest wcześniejszy brak przyjęcia tego sakramentu (kan. $845 \S 1$ ). Nie zawsze jednak te dane są dostępne, a przez to kwerenda skuteczna, a zatem należy stosować przepisy dotyczące wątpliwości faktu przyjęcia chrztu (kan. $845 \S 2 ; 869 \S 1$ ). W takim przypadku, kiedy zostanie udzielony chrzest warunkowy, zostanie sporządzony również nowy zapis w księgach metrykalnych. Formę zapisu powinien określić ordynariusz miejsca.

Nowy zapis w księdze metrykalnej jest możliwy również w sytuacji, w której został sporządzony nowy akt urodzenia, mimo iż są znane dane czasu i miejsca chrztu dziecka przysposobionego. Nowy zapis w księdze metrykalnej zawierać będzie dane zgodnie $\mathrm{z}$ ich brzmieniem $\mathrm{w}$ dokumentach cywilnych, tj. imiona i nazwiska ochrzczonego, datę i miejsce urodzenia, dane przysposabiających, datę i miejsce chrztu lub miejsce sporządzenia nowego wniosku, jeśli wnoszą o taki zapis rodzice przysposabiający, imię i nazwisko szafarza, dane rodziców chrzestnych lub tych, którzy zostali ustanowieni ich zastępcami. Natomiast na marginesie w adnotacjach księgi metrykalnej należy nanieść informację o fakcie, że dziecko zostało przysposobione - ten wpis objęty jest klauzulą utajnione - należy podać także miejsce i numer dotychczasowego aktu chrztu oraz, gdy jest to możliwe, wpisać dane rodziców biologicznych (Dekret o przysposobieniu, 
art. 6). Jest to jedyne istniejące w ustawodawstwie partykularnym uregulowane prawo do przeniesienia danych osobowych związanych z wpisem do księgi ochrzczonych, prawo, które nie jest zawarte w Dekrecie o ochronie danych osobowych, to jednak w tym przypadku jest to ewidentnie przepis, który może być porównywany do tego prawa w prawodawstwie europejskim (RODO, art. 20). Na podstawie sformułowań w dekrecie można wnioskować, że prawo takie przysługuje rodzicom przysposobionym w celu zachowania tajemnicy o fakcie przysposobienia. Dekret nie wspomina o możliwości utworzenia nowego aktu chrztu na wniosek pełnoletniej osoby przysposobionej, ponieważ nie ma żadnych prawnych przesłanek do takiej czynności.

Jest jeszcze jedna istotna kwestia przy utworzeniu nowego aktu chrztu, taka procedura musi zakończyć się utworzeniem klauzuli zabraniającej jego ujawnienia, której treść również podaje dekret KEP, taka klauzula musi być opatrzona również datą wpisu (Dekret o przysposobieniu, art. 6). Taki zabieg utajnienia oznacza, że nie wolno wydawać żadnych odpisów z tego aktu, z wyjątkiem, gdy prosi o niego pełnoletnia osoba, której ten akt dotyczy (Dekret o przysposobieniu, art. 9). Jednak w takim przypadku należy zachować szczególną ostrożność w wypisywaniu tego aktu. Należy wpisać, że osoba ta została przysposobiona - ten fakt jest w tym przypadku jej znany, skoro dotarła do tego zapisu - oraz wpisać, że wszelkie adnotacje zawarte są w innej księdze. Nie można co do zasady wpisać, że dana osoba jest stanu wolnego (de matrimonio nulla adnotatio), ponieważ takie informacje dotyczące zmiany statusu kanonicznego nie będą wpływały do proboszcza tej parafii.

Również prawo do wglądu do ksiąg metrykalnych należy otoczyć szczególną uwagą w takich przypadkach. Może bowiem zachodzić niebezpieczeństwo naruszenia prawa do ochrony danych osobowych osób trzecich (np. rodziców biologicznych lub też rodziców przysposobionych, którzy dla osoby przysposobionej uchodzą za naturalnych, a takimi nie są), a które nie chcą, aby poznano ich dane osobowe. Dlatego w takich przypadkach nie należy umożliwiać bezpośredniego wglądu do księgi metrykalnej, ale przedstawiać wypis z takiej księgi.

W sytuacji, w której wystawia się odpis aktu chrztu, zapisuje się tylko nowe dane osoby przysposobionej $\mathrm{z}$ pominięciem faktu przysposobienia oraz danych o rodzicach biologicznych. Natomiast kiedy metryka jest wystawiana do sakramentu małżeństwa, można wpisać jedynie rodziców 
przysposobionych, ale jeśli istnieje jakakolwiek obawa, czy zachodzi przeszkoda pokrewieństwa, powinno się przesłać do duszpasterza prowadzącego kanoniczne badanie przedmałżeńskie dotyczące braku przeszkód listem poleconym pełny wypis z księgi metrykalnej zawierający dane rodziców biologicznych (Dekret o przysposobieniu, art. 9). Jedynie w przypadku, kiedy duszpasterz wystawia obie metryki chrztu dla nupturientów jest zwolniony z takiego obowiązku, ponieważ tylko wtedy ma pewność, że oboje narzeczeni nie zostali przysposobieni i nie są spokrewnieni. W innym przypadku wydaje się koniecznym poinformowanie proboszcza, ponieważ to on będzie musiał określić brak przeszkód do małżeństwa (kan. 1066).

\subsection{Wyjątek od zasady zgodności z dokumentami anagraficznymi}

Prowadzący księgi metrykalne, zarówno proboszczowie, jak i wikariusze parafialni, ewentualnie osoby pomagające przy ich prowadzeniu, powinny dołożyć wszelkiej staranności, aby zapisy kościelne zawierające personalia i dane osobowe wiernego były zgodne z posiadanymi przez niego dokumentami cywilnymi. To właśnie dlatego przy sporządzaniu zapisów w księgach metrykalnych należy posługiwać się danymi osobowymi zawartymi w analogicznych aktach wydawanych zainteresowanym przez Urząd Stanu Cywilnego. Co więcej, pisowni imion, nazwisk, a także innych danych nie wolno samemu poprawiać wpisując do księgi metrykalnej zmienione dane, które zostały uznane za błędnie wpisane. Nawet w przypadku całkowitej pewności o dokonanym błędzie w pisowni lub stanie faktycznym, należy zaniechać dokonania wpisu i poczekać na poprawienie błędu w cywilnych dokumentach anagraficznych. Dopiero po tej czynności na podstawie nowego dokumentu z Urzędu Stanu Cywilnego można dokonać wpisu w księdze metrykalnej. Zasada zgodności danych osobowych z dokumentów z tymi zapisanymi w księgach metrykalnych nigdy nie została oficjalnie sformułowana w dokumentach prawa kanonicznego, jednak jest powszechnie stosowana, ponieważ poważne odstępstwo od tej zasady mogłoby w przyszłości wprowadzić wątpliwość, czy dany wpis dotyczy rzeczywiście tejże osoby [Wenz 2013, 242-43].

Jedynym wyjątkiem od tej zasady wydaje się być fakt możliwości dodania chrześcijańskiego imienia dziecku. Ustawodawca w KPK/83 zawiera przepis prawny, który stanowi: „rodzice, chrzestni i proboszcz powinni troszczyć się, by nie nadawać imienia obcego duchowi chrześcijańskiemu” 
(kan. 855). Należy zatem wykluczyć wszystkie imiona bałwochwalcze, obraźliwe, niegodne. Zadanie troski o to, by nie nadawać takich imion spoczywa przede wszystkim na rodzicach, następnie na chrzestnych, a w końcu także na proboszczu parafii, który jest właściwym szafarzem chrztu św. ze względu na fakt zamieszkania rodziców dziecka (kan. $857 \S 2 ; 862$ ).

Jednak nie należy zapominać, jakie znaczenie ma imię $\mathrm{w}$ tradycji biblijnej oraz w chrześcijaństwie. Dlatego rozumienie stwierdzenia „obcego duchowi chrześcijańskiemu" można rozumieć również w sytuacjach, w których rodzice nadają dziecku oba imiona, które nie znajdują się w chrześcijańskim katalogu świętych Martyrologium romanum. Zgodnie z kan. 761 KPK/17 proboszcz był zobowiązany do tego, aby czuwać nad tym, żeby dziecko zostało ochrzczone $\mathrm{z}$ imieniem chrześcijańskim, a tym, które takiego nie mają z własnej inicjatywy miał dodać w trakcie chrztu św. imię świętego patrona, zapisując oba imiona w księdze ochrzczonych [Chiappetta $2011,105]$. Skoro przepis prawny nie został wycofany, a jedynie złagodzony można stwierdzić, że prawodawca pragnie, aby przynajmniej jedno $\mathrm{z}$ imion nadanych dziecku dawało mu opiekuna duchowego w postaci świętego patrona i uznany przez Kościół wzór do naśladowania już od najmłodszych lat.

Praktyka pokazuje, że często bywa, iż rodzice przychodzą prosić o chrzest św. dla swojego dziecka już po jego urodzeniu i po otrzymaniu z Urzędu Stanu Cywilnego aktu urodzenia, co oznacza, że imiona już są nadane. Według obowiązujących norm cywilnych każdy obywatel może posiadać tylko dwa imiona, a zmiana imienia nie jest prosta ${ }^{18}$. Zdarzają się jednak sytuacje, w których rodzice przychodzą jeszcze przed porodem, aby poprosić o chrzest św. dla swojego potomka (kan. $867 \S 1$ ). W takim przypadku w rozmowie warto poruszyć fakt imienia i zatroszczyć się o to, by chociaż jedno z imion posiadało odniesienie do jakiegoś świętego. Jest zrozumiałym fakt, że nie musi być to pierwsze imię, gdyż w ten sposób nigdy nie powiększałaby się liczba imion świętych. Natomiast może to być drugie imię lub, jeśli oba imiona są już wpisane w dokumenty, można zachęcić rodziców, aby zdecydowali się na chrzcie św. dodać trzecie imię, które należy dopisać do rubryki „adnotacje” w księdze ochrzczonych, podobnie do praktyki, jaka była do niedawna stosowana $\mathrm{w}$ tradycji polskiej przy sa-

${ }^{18}$ Ustawa z dnia 17 października 2008 r. o zmianie imienia i nazwiska, Dz. U. z 2016 r., poz. 10 z późn. zm. 
kramencie bierzmowania. Taka praktyka, to najlepsze rozwiązanie duszpasterskie dla szafarza sakramentu, który może wykorzystać moment do uświadomienia prawdy o świętych obcowaniu. Jest to także rozwiązanie, które przynosi duchową korzyść przyjmującemu chrzest św., gdyż od momentu wejścia do wspólnoty wiernych ma swojego szczególnego orędownika przed Bogiem, który modli się za niego. Jest to zarazem jedyna możliwość, w świetle powyższych przesłanek, uznania za obowiązujący kan. 855 w interpretacji opierającej się na hermeneutyce ciągłości.

\section{PRAWO WGLĄDU W DANE OSOBOWE ZAPISANE W KSIĘGACH METRYKALNYCH}

W Dekrecie ogólnym Konferencji Episkopatu Polski dotyczącym ochrony danych osobowych znajduje się artykuł odnośnie do prawa do informacji o przetwarzaniu danych. Nadaje on osobie, której dane dotyczą (w przypadku nieletnich zaś rodzicom lub prawnie ustanowionym opiekunom) uprawnienie „do uzyskania od administratora potwierdzenia, czy przetwarzane są jej dane osobowe, a jeżeli ma to miejsce, jest uprawniona do uzyskania dostępu do nich" (Dekret ODO, art. 11 ust. 1). W celu uzyskania potwierdzenia przetwarzanych danych lub udokumentowania jakiegoś faktu „każdy ma prawo do żądania i otrzymania, osobiście lub za pośrednictwem prawnie ustanowionego pełnomocnika, certyfikatów, wyciągów, świadectw, w postaci kopii lub dokumentu autentycznego, zawierających dane jego dotyczące. Wyłączeniu podlegają dane, które jako nie pochodzące od wnioskodawcy, są objęte tajemnicą na mocy prawa lub nie można ich oddzielić od danych dotyczących osób trzecich i ze względu na poufność wymagają ochrony" (Dekret ODO, art. 11 ust. 4).

Każdy ma prawo do uzyskania dostępu do danych osobowych, które go dotyczą, a w przypadku dostępu do księgi ochrzczonych możemy mówić o każdym wiernym. Nie jest to prawo nowe, uznawane było już przed wejściem w życie tego dokumentu [Wenz 2008, 113-14]. Jednak po raz pierwszy w tak jasny sposób zostało ono sformułowane. To prawo wierny może zrealizować przez żądanie wystawienia certyfikatów, wyciągów, świadectw, kopii lub dokumentu autentycznego, uzyskując w ten sposób potwierdzenie na piśmie, jakie dane są przetwarzane w księgach metrykalnych. W przypadku innych zbiorów danych (np. kartoteka parafialna) 
każda osoba, której dane dotyczą może skorzystać z realizacji swojego prawa poprzez podobne praktyki. Prawo do żądania i otrzymania takich danych wystawionych na właściwych drukach oraz zgodnie $\mathrm{z}$ obowiązującą praktyką administracji kościelnej rodzi po stronie administratorów danych osobowych obowiązek wydania takich dokumentów. W przypadku ksiąg metrykalnych taki obowiązek spoczywa na proboszczach. Prawo to jest konieczne nie tylko do wykazania swojego statusu kanonicznego, ale również ma swoje uzasadnienie $\mathrm{w}$ prawie do żądania sprostowania danych, jeżeli dane te są nieprawidłowe (Dekret ODO, art. 12 ust. 1). Należy jednak podkreślić, że na wyrażone żądanie o informacji dotyczącej przetwarzania danych dekret KEP nie podaje stosownego terminu, a zatem należy stosować przepisy wynikające z powszechnego prawa kanonicznego zawartego w KPK/83. W kan. 57 jest mowa o terminie 3 miesięcy i należy zastosować tutaj takie maksymalne ograniczenie czasowe.

Prawo do uzyskania dostępu do danych nie jest prawem absolutnym, jeśli przetwarzane dane dotyczą również osób trzecich nie mogą zostać ujawnione ze względu na prawo tychże osób, podobnie jeśli dane zostały utajnione $\mathrm{z}$ jakiegoś innego prawnie uzasadnionego powodu. Wtedy należy udzielić informacji, aby nie naruszyć prawa osoby proszącej, poprzez wydanie odpisu lub nawet tylko wypisu. Odpis to wierne odtworzenie całości danych osobowych przetwarzanych przez administratora to znaczy, że jest to dokument zawierający wierny zapis wszystkich adnotacji znajdujących się w księdze chrztów (akt chrztu ze wszystkimi adnotacjami dotyczącymi statusu kanonicznego osoby). Wypis to zapisanie wybranych informacji zgromadzonych przez administratora w przypadku, kiedy w danym celu nie są potrzebne wszystkie informacje zgromadzone w księgach metrykalnych (np. świadectwo chrztu skrócone potrzebne do I Komunii Świętej lub bierzmowania). Również w przypadku wyrażenia żądania otrzymania odpisu, wypisu czy innych kopii należy zastosować przepisy ogólne prawa kanonicznego co do terminu trzech miesięcy (por. kan. 57).

\section{ODPOWIEDZIALNOŚĆ KARNA ZA NARUSZANIE PRAW ZWIĄZANYCH Z OCHRONĄ DANYCH OSOBOWYCH}

Ze względu na obowiązujące przepisy dotyczące ochrony danych osobowych w Kościele katolickim w Polsce troska o księgi metrykalne nabrała 
jeszcze większego znaczenia, co więcej należy szanować wszelkie prawa osób związane z ich danymi osobowymi, czyli prawo do wglądu, prawo do sprostowania, prawo do ograniczenia przetwarzania lub nawet, w niektórych przypadkach, prawo do usunięcia danych. Należy dokładać wszelkich starań, aby wiernym nie zostało odmówione to, do czego mają prawo w kwestiach danych osobowych w księdze ochrzczonych lub innych księgach metrykalnych. Podobnie jak nie można ograniczać praw osób nieochrzczonych, których dane znajdują się w parafii. Drugie niebezpieczeństwo związane jest $\mathrm{z}$ troską o przechowywanie ksiąg metrykalnych w miejscu odpowiednim tak, aby nie doszło do „naruszenia ochrony danych osobowych”, które w Dekrecie jest wytłumaczone jako „naruszenie bezpieczeństwa prowadzące do przypadkowego lub niezgodnego z prawem zniszczenia, utracenia, zmodyfikowania, nieuprawnionego ujawnienia lub nieuprawnionego dostępu do danych osobowych przesyłanych, przechowywanych lub w inny sposób przetwarzanych" (Dekret ODO, art. 5 pkt 8). Za naruszenia związane $\mathrm{z}$ danymi osobowymi zawartymi w księgach metrykalnych grożą sankcje kościelne związane z nadużyciem władzy kościelnej lub urzędu (kan. 1389) oraz z naruszeniem obowiązku służbowego i może skutkować odwołaniem lub pozbawieniem urzędu (Dekret ODO, art. 42).

\section{ZAKOŃCZENIE}

Dekret ogólny Konferencji Episkopatu Polski pomaga dostosować prawodawstwo kościelne do wymogów prawa europejskiego. Ten proces miał na celu fakt, aby Kościół katolicki w Polsce nadal cieszył się autonomią w kwestiach stosowania przepisów o ochronie danych osobowych. Jest zatem istotnym uświadamianie duszpasterzy o tym, że w sposób bezpośredni nie podlegają przepisom RODO, ale dekretowi o ochronie danych osobowych Konferencji Episkopatu Polski. Taka świadomość pomoże z pewnością uniknąć wielu nadużyć związanych z żądaniami usunięcia zapisów w księdze ochrzczonych lub też wprowadzaniu nieuprawnionych zmian w tychże księgach.

Prawo polskie oraz prawo europejskie przyznaje autonomię o ustanowieniu i stosowaniu własnego prawodawstwa dotyczącego ochrony danych osobowych kościołom i związkom wyznaniowym. Na tę autonomię Kościół katolicki w tym przypadku się powołuje. Nie ma to na celu ograniczania 
praw osób do ochrony swoich danych osobowych, lecz podstawowe prawo Kościoła do realizowania swojej misji zbawienia dusz. Jednym z aspektów tej misji jest życie sakramentalne, o którym to fakty zapisane są w księgach metrykalnych i nie mogą być zmieniane na każde żądania nawet osób, których one dotyczą.

\section{PIŚMIENNICTWO}

Adamczyk, Jerzy. 2017. „Wizytacja dziekańska w aspekcie kanoniczno-duszpasterskim.” Prawo Kanoniczne 60, nr 3:73-105. doi: 10.21697/pk.2017.60.3.04

Chiappetta, Luigi. 2011. Il Codice di Diritto Canonico. Commento giuridico-pastorale. Vol. 2. Ed. 3. Bologna: Dehoniane.

Gręźlikowski, Janusz. 2014. „Trydencka reforma i odnowa Kościoła. Refleksje w 450. rocznicę od zakończenia obrad Soboru Trydenckiego (1545-1563)." Studia Włocławskie 16:126-46.

Janczewski, Zbigniew. 1997. „Prawodawstwo Konferencji Episkopatu Polski i Prymasów w zakresie sakramentów wtajemniczenia chrześcijańskiego.” Prawo Kanoniczne 40, nr 3-4:125-202.

Kotecki, Radosław. 2009. „Rejestracja metrykalna wiernych w świetle potrydenckiego ustawodawstwa Kościoła Katolickiego (ze szczególnym uwzględnieniem prawodawstwa diecezji Chełmińskiej, Gnieźnieńskiej, Płockiej i Włocławskiej)." Nasza Przeszłość 112:135-79.

Kufel, Robert R. 2005. Kancelaria, Registratura i archiwum parafialne na ziemiach polskich od XII do początku XXI wieku. Zielona Góra: Księgarnia Akademicka Bogusław Mykietów.

Kumor, Bolesław. 1966. „Metryki parafialne w archiwach diecezjalnych.” Kwartalnik Historii Kultury Materialnej 14, z. 1:65-75.

Kurpas, Józef. 1961. „Początki ksiąg metrykalnych.” Archiwa Biblioteki i Muzea Kościelne 11:5-41.

Moskal, Tomasz. 2005. „Historia ksiąg metrykalnych Kościoła katolickiego na ziemiach polskich." Archiwariusz. Biuletyn Archiwum Archidiecezjalnego w Poznaniu 1:55-83.

Różański, Mieczysław. 2005. „Księgi metrykalne w prawodawstwie polskim.” Archiwariusz. Biuletyn Archiwum Archidiecezjalnego w Poznaniu 1:133-42.

Sztafrowski, Edward. 1992. „Ponadparafialni współpracownicy biskupa diecezjalnego.” Prawo Kanoniczne 35, nr 3-4:25-56.

Wenz, Wiesław. 2008. Kancelaria parafialna jako przestrzeń kościelnego posługiwania. Studium kanoniczno-pastoralne. Wrocław: PWT Wrocław.

Wenz, Wiesław. 2013. „Kancelaria parafialna.” W Parafia w prawie kanonicznym $i$ w prawie polskim, red. Sławoj L. Głódź, Józef Krukowski, i Mirosław Sitarz, 217-62. Lublin: Towarzystwo Naukowe KUL. 


\section{Zmiany i adnotacje w księgach metrykalnych $\mathrm{z}$ uwzględnieniem kwestii problematycznych $\mathrm{w}$ tej materii w obowiązujących przepisach o ochronie danych osobowych w Polsce}

\section{Streszczenie}

Prowadzenie ksiąg metrykalnych stanowi niezwykle istotną część pracy kancelaryjnej proboszcza i jego współpracowników. Jest to związane z możliwością potwierdzenia statusu kanonicznego każdego wiernego, który przyjmował sakramenty w danej parafii oraz dokonywał istotnych aktów, które wpłynęły na jego sytuację kanoniczną. Dlatego prowadzenie ksiąg metrykalnych powinno być zawsze rzetelne, staranne i z zachowaniem przepisów prawa.

W świetle obowiązujących przepisów o ochronie danych osobowych w Kościele katolickim w Polsce należy również uwzględnić podstawowe prawa przysługujące wiernym co do prowadzenia ksiąg metrykalnych. Jednak z różnych względów zapisy zawarte w księgach metrykalnych różnią się często ze stanem faktycznym, dlatego niezbędne jest dokonywanie zmian metrykalnych, które mogą odbyć się za zgodą kompetentnej władzy kościelnej. W tej materii pojawiają się niektóre kwestie problematyczne, które wymagają szczególnej uwagi i znajomości procedur przewidzianych prawem ze strony odpowiedzialnych za prowadzenie kancelarii parafialnej. Wśród tych kwestii należy wymienić sprawy: apostazji, przysposobienia dziecka, transseksualizmu i obojnactwa, zasady zgodności z dokumentami cywilnymi, która jednak może dopuszczać wyjątki.

Troska o właściwe prowadzenie ksiąg metrykalnych i realizacja obowiązku dokonywania zmian metrykalnych na wniosek zainteresowanego i zgodnie z prawem jest troską o właściwe przetwarzanie danych osobowych przechowywanych w księgach metrykalnych. Naruszenie praw dotyczące ochrony danych osobowych związane jest z możliwością otrzymania sankcji kościelnych wynikających $\mathrm{z}$ przepisów prawa powszechnego, jak i prawa partykularnego.

Słowa kluczowe: kancelaria parafialna; księgi metrykalne; księga ochrzczonych; ochrona danych osobowych; status kanoniczny wiernych

\section{Changes and Notations in Parochial Registers Including Problematic Issues in this Matter According to Applicable Laws about Privacy in Poland}

\section{Summary}

Each parish is to have parochial registers. The parish priest is to see to it that these registers are accurately inscribed and carefully preserved. It provides proofs of receiving sacraments by Christian faithful. For this reason, the parochial register should always be kept carefully according to the norm of law.

The Catholic Church, with respect to personal data protection, is to observe the rights of Christian faithful. Although parochial registers differ from state documents it is necessary to update all changes with the approval of the competent ecclesiastical authority. There may occur problematic issues, which require the knowledge of procedures expressed in canon law. We can mention among others apostasy, adoption 
of a child, transsexualism or issues of hermaphroditism. We can also add the principle of compliance with civil documents.

The solicitude for keeping of parochial registers and mandatory of making changes upon request of concerned. The personal data breach is related with the imposition of ecclesiastical sanctions provided both universal and particular law.

Key words: parish office; parochial registers; register of baptisms; protection of the privacy; canonical status of the faithful

Information about Author: Rev. BARTosz Trojanowski, Ph.D. - Metropolitan Curia in Wrocław; Plac Katedralny 14, 50-329 Wrocław, Poland; e-mail: b.trojanowski@ hadak.pl; https://orcid.org/0000-0003-0158-1647 